\title{
16S rRNA targeted RT-PCR for the detection of Vibrio penaeicida, the pathogen of cultured kuruma prawn Penaeus japonicus
}

\author{
K. Genmoto, T. Nishizawa*, T. Nakai, K. Muroga \\ Faculty of Applied Biological Science, Hiroshima University, Kagamiyama 1-4-4, Higashihiroshima 739, Japan
}

\begin{abstract}
Vibrio penaeicida is the causative bacterium of vibriosis in cultured kuruma prawn Penaeus japonicus in Japan. To develop a specific and sensitive method for the detection of the pathogen, a species-specific sequence in the $165 \mathrm{rRNA}$ of $V$ penaeicida was determined and a polymerase chain reaction (PCR)-based method was devised on the basis of the sequence. Prior to sequencing, a part of the variable regions of the $16 \mathrm{~S}$ rRNA was amplified by using primers designed from 2 conserved regions according to previously reported data on Vibrionaceae. The region of the 16S rRNA. (nucleotide numbers 440 to 490 in Escherichia coli 16S rRNA) obtained by this procedure was found to be species-specific for $V$ penaeicida. It was confirmed that PCR and RT (reverse transcription)-PCR amplifications with a sense primer designed from the $V$ penaeicida-specific sequence were both able to differentiate $V$. penaeicida from other prawn-pathogenic vibrios. 16S rRNA-targeted RT-PCR was demonstrated to have 100 times higher sensitivity than 16S rDNA-targeted PCR and $10 \mathrm{fg}$ of total nucleic acids extracted from cultured bacterial cells was sufficient to yield the visible fragment in gel electrophoresis. These results indicate that RT-PCR amplification with this primer is useful for specific and sensitive detection of $V$. penaelcida.
\end{abstract}

KEY WORDS: Vibrio penaeicida $\cdot$ RRNA.PCR Kuruma prawn Vibriosis

\section{INTRODUCTION}

It is well known that several species of the genus Vibrio, for example Vibrio parahaemolyticus and $V$. alginolyticus, cause septicemia in marine crustaceans resulting in economic damage, particularly among cultured penaeid prawns (Brock \& Lightner 1990, Stewart 1993). Vibriosis has also been the most serious disease problem in cultured kuruma prawn Penaeus japonicus in Japan, and one species of Vibrio (Vibrio sp. PJ) has been reported as the causative agent of the disease (Takahashi et al. 1985, de la Peña et al. 1993). This causative bacterium was confirmed to be a new species and named Vibrio penaeicida sp. nov. (Ishimaru et al. 1995). As is the case with other vibrios pathogenic to prawn and shrimp, V. penaeicida was demonstrated to be a part of the ubiquitous microflora

•E-mail: jjnishi@ue.ipc.hiroshima-u.ac.jp in apparently healthy kuruma prawns, and in their culture environment, which will produce vibriosis in a compromised (stressed) host (de la Peña et al. 1992). Recently, the dynamics of $V$. penaeicida in kuruma prawns experimentally infected by oral intubation was studied by a viable cell count method and an indirect fluorescent antibody technique (de la Peña et al. 1995). The results of that study suggested that the pathogen probably multiplies in the stomach in the establishment stage of infection; however, exact site(s) for initial multiplication could not be determined due to abundant presence of other vibrios. To solve this problem, an alternative, more sensitive method to detect the pathogen is required.

Ribosomal RNA (rRNA) is present in high copy numbers in a growing bacterial cell and there are conserved and variable sequences in rRNA at the genus and species levels of bacteria (Woese 1987). These features make rRNA suitable as a target for hybridization using DNA probes complementary to rRNA and 
polymerase chain reaction. (PCR) amplification. The 16S rRNA-targeted hybridization and PCR techniques have been applied for identification and detection of several fish pathogens (Rehnstam et al. 1989, Mattsson et al. 1993, Martínez-Picado et al. 1994, Toyama et al. 1994). In this study, a species-specific sequence in the $16 \mathrm{~S}$ rRNA of Vibrio penaeicida was analyzed and PCRbased methods to detect $16 \mathrm{~S}$ rDNA or rRNA of the pathogen were examined.

\section{MATERIALS AND METHODS}

Bacterial strains and culture condition. Seven strains of Vibrio penaeicida were isolated from diseased kuruma prawns in different places in Japan. Thirteen Vibrio species reported to be pathogenic to prawns, and Escherichia coli, were used for comparison, even though these strains were not isolated from prawns (Table 1). They were grown at $25^{\circ} \mathrm{C}$ for 18 to $20 \mathrm{~h}$ while being shaken in ZoBell's $2216 \mathrm{E}$ broth $10.5 \mathrm{~g}$ peptone, $0.1 \mathrm{~g}$ yeast extract, $0.01 \mathrm{~g} \mathrm{FePO}_{4}, 100 \mathrm{ml}$ filtered sea water) for $V$. penaeicida or in tryptic soy broth (Nissui) prepared with $1 / 2$-diluted sea water for other vibrios and Escherichia coli.

Extraction of bacterial nucleic acids. Bacterial cultures were harvested by centrifugation at $10000 \times \mathrm{g}$ for 10 min and the resultant pellets were lysed with $1 \%$ $\mathrm{SDS} / 1 \mathrm{mg} \mathrm{ml}^{-1}$ proteinase $\mathrm{K}$ solution. Bacterial nucleic acids were extracted by a phenol-chloroform-isoamylalcohol $(25: 24: 1, \mathrm{v} / \mathrm{v} / \mathrm{v})$ mixture and a chloroformisoamylalcohol $(24: 1, \mathrm{v} / \mathrm{v})$ mixture. The nucleic acids obtained were precipitated with sodium acetate $(\mathrm{pH} 5.2)$ and ethanol, and resuspended in water treated with diethyl pyrocarbonate (DEPC).

Sequencing of PCR products from $16 \mathrm{~S}$ rDNA. An antisense primer, 5'-CCCGGGATCCGATTACCAGGGTATCTAATC-3' (R-GEN), and a sense primer, 5'CCGAATTCAGCAGTGTGGAATATTGCA-3' (F-GEN), were used for PCR amplification of a partial 16S rDNA. The R-GEN primer was complementary to a conserved region of $16 \mathrm{~S}$ rRNA of Vibrionaceae (base positions 786 to 805 in Escherichia coli $16 \mathrm{~S}$ rRNA; KitaTsukamoto et al. 1993) with an additional 10 base linker sequence (underlined) containing Smal and BamHI recognition sites. The F-GEN primer was complementary to another conserved region of $16 \mathrm{~S}$ rRNA of Vibrionaceae (base positions 352 to 371 ) with a 7 base linker sequence (underlined) containing an EcoRI recognition site.

PCR amplification was carried out in a $100 \mu \mathrm{l}$ reaction mixture containing the extracted bacterial nucleic acids (ca $10 \mathrm{ng}$ ), $10 \mathrm{mM}$ Tris- $\mathrm{HCl}(\mathrm{pH} 8.3), 50 \mathrm{mM} \mathrm{KCl}$, $2 \mathrm{mM} \mathrm{MgCl}_{2}, 0.2 \mathrm{mM}$ each dNTP, 10 pmol each. primer and 2.5 U Ampli Taq DNA Polymerase (Perkin-Elmer)
Table 1. Bacterial strains used in this study. All strains of Vibrio penacicida were isolated from kuruma prawn. JCM: Japan Collection of Microorganisms; ATCC: American Type Culture Collection: $\mathrm{NCMB}$ : National Collection of Marine Bacteria; NCIC: National Collection of Type Cultures. ${ }^{1}$ type strain

\begin{tabular}{|c|c|}
\hline Species & Strain (Source) \\
\hline Vibrio penaeicida & $\begin{array}{l}\text { KH-1 (= JCM 9123, Kagoshima Pref.) } \\
\text { PD-A (= JCM 9124, Hiroshima Pref.) } \\
\text { KA-13 (= JCM 9125, Yamaguchi Pref.) } \\
\text { ESV-8701 (= JCM 9192, Ehime Pref.) } \\
\text { PO-1 (= JCM 9193, Hiroshima Pref.) } \\
\text { KO-1 (= JCM 9194, Oita Pref.) } \\
\text { KT-1 (Yamaguchi Pref.) }\end{array}$ \\
\hline$V$ alginolyticus & NCMB $1903^{\top}$ \\
\hline$V$ anguillarum & ATCC $19264^{T}$ \\
\hline$V$ cholerae (non-01) & PS-7701 (Ayu, Shiga Pref.) \\
\hline V damsela & $\operatorname{ATCR} 33.530^{\mathrm{T}}$ \\
\hline V. fluvialis & $\operatorname{NCTC} 11327^{\mathrm{T}}$ \\
\hline V. harveyi & ATCC $14126^{\mathrm{T}}$ \\
\hline$V$. nereis & $\operatorname{ATCC} 25917^{\top}$ \\
\hline V. parahaemolyticus & ATCC $1.7802^{\mathrm{T}}$ \\
\hline$V$ pelagius I & ATCC $25916^{\top}$ \\
\hline V. proteolyticus & NCMB $1326^{\mathrm{T}}$ \\
\hline$V$ splendidus II & ATCC 25914 \\
\hline V. tubiashii & ATCC $19109^{\mathrm{T}}$ \\
\hline$V$ vulnificus ll & $\operatorname{ES}-7601(=\operatorname{ATCC} 33147)$ \\
\hline Escherichia coli & WP-2 \\
\hline
\end{tabular}

with an automatic thermal cycler (Astec PC-700). The thermal profile involved 25 cycles of denaturation at $95^{\circ} \mathrm{C}$ for $40 \mathrm{~s}$, annealing at $55^{\circ} \mathrm{C}$ for $40 \mathrm{~s}$ and extension at $72^{\circ} \mathrm{C}$ for $40 \mathrm{~s}$. The results of amplification were analyzed by $1.5 \%$ agarose gel electrophoresis. The PCR products digested with BamHI and EcoRI were purified by agarose gel electrophoresis using a GENECLEAN II kit (BIO 101) and were ligated into pBluescript (Stratagene) using a ligation kit (Takara) to transform Escherichia coli (DH5 $\alpha$ ). The plasmids containing inserts were purified by the alkaline lysis method and the polyethylene glycol (MW: 6000) precipitation method.

The inserts in the plasmids were sequenced using a Taq Dye Primer Cycle Sequencing kit (ABI) and an automatic sequencer (ABI 373A). Several clones were used for determination of sequence to reduce the potential errors. The sequence data obtained were assembled and analyzed with DNASIS (Hitachi) and GENETYX (SDC). The sequence data for 16S rRNA of 9 Vibrio species including fish and shellfish pathogens (Vibrio anguillarum, $V$. campbellii, $V$. diazotrophicus, $V$. hollisae, $V$. proteolyticus, $V$. vulnificus, $V$. alginolyticus, $V$. parahaemolyticus, and $V$. cholerae) were obtained from GenBank nucleotide sequence libraries and used for the comparative study.

RT-PCR amplification of $16 \mathrm{~S}$ rRNA. A sense primer, 5'-GTGTGAAGTTAATAGCTTCATATC-3' (P-PJF primer), was designed based on the sequence of Vibrio 
penaeicida 16S rRNA at the base positions 455 to 478 . The R-GEN primer without the linker sequence was used as the reverse primer. The cDNAs to the $16 \mathrm{~S}$ rRNA were synthesized in a reaction mixture containing $10 \mathrm{mM}$ Tris- $\mathrm{HCl}(\mathrm{pH}$ 8.3), $50 \mathrm{mM} \mathrm{KCl}, 5 \mathrm{mM}$ $\mathrm{MgCl}_{2}, 0.2 \mathrm{mM}$ each dNTP, $10 \mathrm{pmol}$ antisense primer,

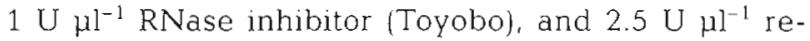
verse transcriptase (M-MLV, USB) at $42^{\circ} \mathrm{C}$ for $30 \mathrm{~min}$. PCR amplification of the CDNA was performed using the same procedure as described above except that the annealing temperature was $59^{\circ} \mathrm{C}$, the final concentration of $\mathrm{MgCl}_{2}$ was $2.5 \mathrm{mM}$, and the number of thermal cycles was 30 .

\section{RESULTS AND DISCUSSION}

Kita-Tsukamoto et al. (1993) previously determined the $16 \mathrm{~S}$ rRNA sequences of 50 strains of marine bacteria including 34 strains of the family Vibrionaceae, and showed that a region between base positions 440 and 490 of $16 \mathrm{~S}$ rRNA was very variable among them. This was presumed to be true in Vibrio penaeicida as

Position (Escherichia colinumbering) in 165 rRNA

\begin{tabular}{|c|c|c|}
\hline 380 & 440 & 780 \\
\hline Conserved region & Variable region & - Conserved region \\
\hline Primer F-GEN & & Primer R-GEN \\
\hline $352-371$ & & $786-805$ \\
\hline \multicolumn{3}{|c|}{$454 \mathrm{bp}$} \\
\hline & Primer P-PJF & Primer R-GEN \\
\hline & $455-478$ & $786-805$ \\
\hline & 349 & $\mathrm{bp}$ \\
\hline
\end{tabular}

Fig. 1 Schematic illustration of the physical map of the PCR primers and 16S rRNA molecules of Vibrio species, showing variable and conserved regions according to Kita-Tsukamoto et al. (1993)

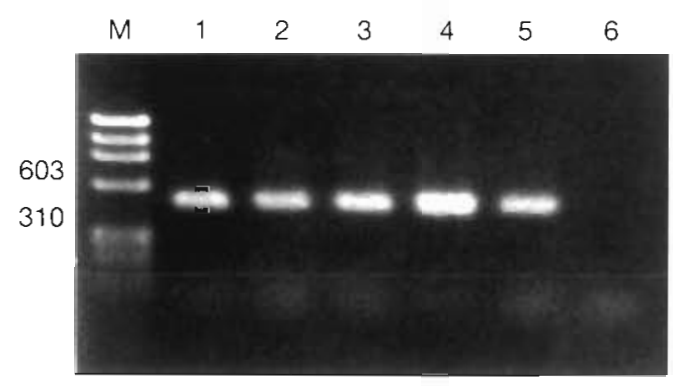

Fig. 2. Agarose gel electrophoretic analysis of the PCR products from nucleic acids of Vibrio penaeicida strains and other Vibrio species with the primers R-GEN and F-GEN. Lanes: M, length marker ( $\phi$ X174/HaeIIl digest); $1, V$. penaeicida $\mathrm{KH}-1$; $2, \mathrm{KA}-13 ; 3, \mathrm{KO}-1 ; 4, V$ anguillarum $;, V$ harvey $i, 6$, negative control (containing no template) well. Thus, to amplify this variable region of $V$. penaeicida, R-GEN primer (786 to 805) and F-GEN primer (352 to 371 ) were designed as antisense and sense primers, respectively, from conserved regions flanking the variable region (Kita-Tsukamoto et al. 1993). In addition, the product expected to be amplified by these primers is of a suitable size (450 bp) for agarose gel electrophoresis analysis (Fig. 1).

The target region of the rDNAs of 7 strains of Vibrio penaeicida, 4 other species of Vibrio ( $V$. anguillarum, $V$. harveyi, $V$. alginolyticus, $V$. parahaemolyticus), and Escherichia coli were all amplified by PCR using the RGEN and F-GEN primers. Results of PCR in 3 strains of $V$. penaeicida, $V$. anguillarum, and $V$. harveyi are shown in Fig. 2. In the next step, the PCR products from 7 strains of $V$ penaeicida were cloned and sequenced. Multiple alignments of partial 16S rRNA sequences (352 to 589) of $V$. penaeicida and 9 fish-and

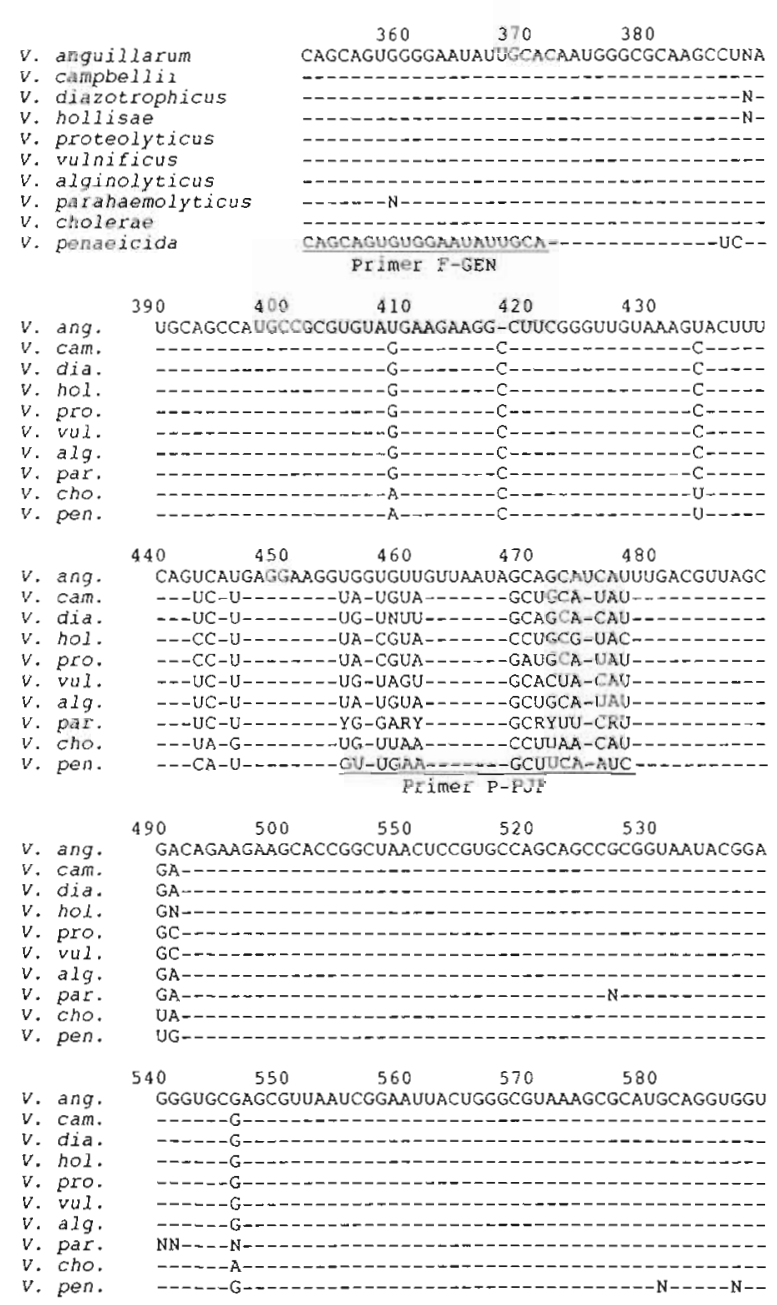

Fig. 3. Multiple alignments of the $16 \mathrm{~S}$ rRNA sequences of Vibrio penaeicida and 9 other Vibrio species. Abbreviations for nucleotides used in the alignment: $R=$ purine $(A$ or $G$ ): $\mathrm{Y}=$ pyrimidine $(\mathrm{C} \text { or } \mathrm{U})_{i} \mathrm{~N}=\mathrm{A}, \mathrm{C}, \mathrm{G}$, or $\mathrm{U}$ 
shellfish-pathogenic Vibrio species are shown in Fig. 3. There were no substitutions in the determined sequences of $16 \mathrm{~S}$ rRNA among the 7 strains of $V$. penaeicida, while 18 substitutions were observed in the vari-

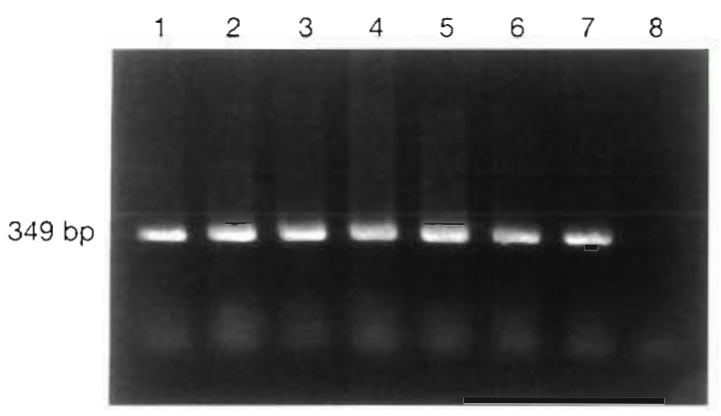

Fig. 4. Analysis of the PCR products from nucleic acids of 7 strains of Vibrio penaeicida with the primer P-PJF and primer R-GEN without linker sequence. Lanes: $1, \mathrm{KH}-1 ; 2, \mathrm{KT}-1$; 3, KA-13; 4, PD-A; 5, ESV-8701; 6, KO-1; 7, PO-1; 8, negative control (containing no template)

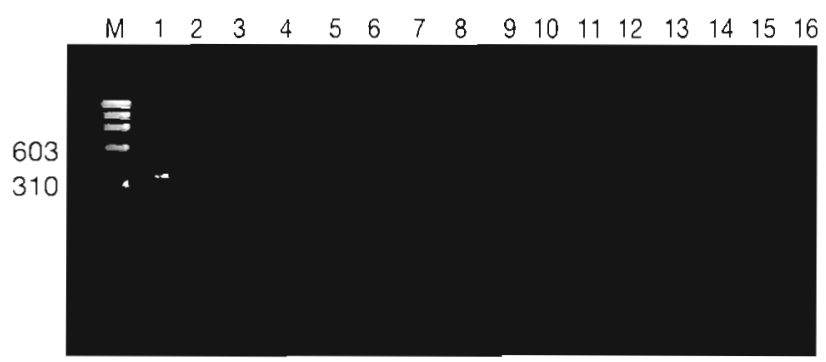

Fig. 5. Agarose gel electrophoretic analysis of the PCR products from nucleic acids of Vibrio penaeicida $\mathrm{KH}-1$ and 13 other Vibrio species with the primer P-PJF and primer R-GEN without linker sequence. Lanes: $M$, length marker ( $\phi$ X174) HaellI digest): $1, V$ penaeicida $\mathrm{KH}-1 ; 2, V$ alginolyticus; $3, V$. anguillarum; $4, V$. cholerae (non-O1); $5, V$. damsela; $6, V$. fluvialis; $7, V$ harveyi $8, V$ nereis; $9, V$ parahaemolyticus; $10, V$. pelagius $\mathrm{l} ; 11, \mathrm{~V}$. proteolyticus; $12, \mathrm{~V}$. splendidus $\mathrm{II}_{i} 13, \mathrm{~V}$. tubiashii $14, V$. vulnificus $I_{i} 15$, Escherichia coli; 16 , negative control (containing no template)

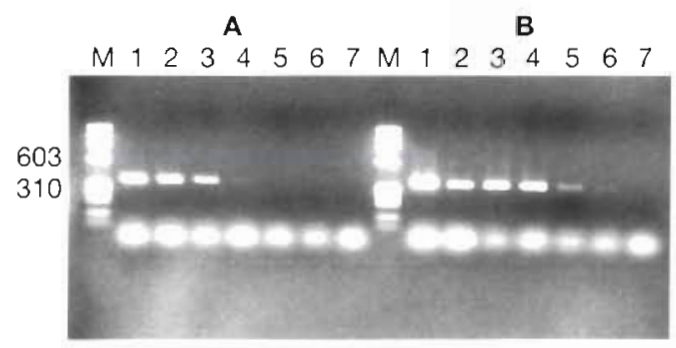

Fig. 6. Detection limit of purified nucleic acids from Vibrio penaeicida $\mathrm{KH}-1$ by $\mathrm{PCR}$ and RT-PCR with the primer P-PJF and primer $R-G E N$ without linker sequence. $A$ : products by PCR; B: products by RT-PCR. Lanes: $M$, length marker $\left(\phi \times 174 /\right.$ Haelll digest); $1,1 \mathrm{ng}_{;} 2,100 \mathrm{pg} ; 3,10 \mathrm{pg} ; 4,1 \mathrm{pg} ;$ $5,100 \mathrm{fg} ; 6,10 \mathrm{fg} ; 7,1 \mathrm{fg}$ able region (440 to 480 ) between $V$. penaeicida and others. Especially, 15 out of the 18 substitutions were concentrated between 455 and 478 . Furthermore, no sequences having a high similarity with this region of $V$ penaeicida $16 \mathrm{~S}$ rRNA were found in the GenBank data base.

An oligonucleotide identical to the species-specific sequence of Vibrio penaeicida $16 \mathrm{~S}$ rRNA (455 to 478) was synthesized and used as a sense primer (P-PJF) to examine its specificity in PCR amplification. Although R-GEN primer without the linker sequence used as an antisense primer was 4 bases shorter than P-PJF, it had the same Tm as P.PJF because of its high GC\%. A single PCR product with the expected length (350 bps) was amplified from the extracted nucleic acids of all 7 strains of $V$. penaeicida (Fig. 4), while no PCR products were obtained from those of 13 other Vibrio species or Escherichia coli (Fig. 5). The same results were observed using RT-PCR amplification (data not shown). These results indicate that the present PCR or RT-PCR amplification with P-PJF and R-GEN primers is useful for specific detection of $V$. penaeicida.

To compare the sensitivity of PCR and RT-PCR amplifications, serial 10 -fold dilutions of nucleic acids extracted from Vibrio penaeicida strain $\mathrm{KH}-1$ were prepared and tested. The PCR amplification needed at least $1 \mathrm{pg}$ of the nucleic acids to yield a visible fragment on agarose gel electrophoresis, while in RT-PCR $10 \mathrm{fg}$ of nucleic acids were sufficient to yield a visible fragment (Fig. 6). This higher sensitivity of RT-PCR compared with PCR can be explained by the fact that RT-PCR amplification could target both rDNA and IRNA.

In the present study, a species-specific sequence of Vibrio penaeicida $16 \mathrm{~S}$ rRNA was demonstrated and RT-PCR amplification was developed as a specific and sensitive method for the detection of the pathogen. In applying the present RT-PCR procedure, an appropriate method for the extraction of bacterial nucleic acids should be developed to detect $V$. penaeicida from prawns where many kinds of inhibitors to PCR enzymes and/or RNase will be present.

\section{IITERATURE CITED}

Brock JA, Lightner DV (1990) Diseases caused by microorganisms. In: Kinne $\mathrm{O}$ (ed) Diseases of marine animals, Vol III. Biologische Anstalt Helgoland, Hamburg, p 245-349

de la Peña LD, Momoyama K, Nakai I, Muroga K (1992) Detection of the causative bacterium of vibriosis in kuruma prawn, Penaeus japonicus. Fish Pathol 27:223-228 de la Pena LD, Nakai T, Muroga K (1995) Dynamics of Vibrio sp. PJ in organs of orally infected kuruma prawn, Penaeus japonicus. Fish Pathol 30:39-45

de la Peña LD, Tamaki T, Momoyama K, Nakai T, Muroga K (1993) Characteristics of the causative bacterium of vibrio- 
sis in the kuruma prawn, Penaeus japonicus. Aquaculture 115:1-12

Ishimaru K, Akagawa-Matsushita M, Muroga K (1995) Vibrjo penaeicida sp. nov., a pathogen of kuruma prawns (Penaeus japonicus). Int J Syst Bacteriol 45:134-138

Kita-Tsukamoto K, Oyaizu H, Nanba K, Simidu U (1993) Phylogenetic relationships of marine bacteria, mainly members of the family Vibrionaceae, determined on the basis of 16S rRNA sequences. Int J Syst Bacteriol 43:8-19

Martinez-Picado J, Blanch AR, Jofre J (1994) Rapid detection and identification of Vibrio angullarum by using a specific oligonucleotide probe complementary to 16S rRNA. Appl environ Microbiol 60:732-737

Mattsson JG, Gersdorf H, Jansson E, Hongslo T, Göbel UB, Johansson KE (1993) Rapid identification of Renibacterium salmoninarum using an oligonucleotide probe complementary to 165 rRNA. Mol Cell Probes 7:25-33

Responsible Subject Editor: J. E. Stewart, Dartmouth, Nova Scotia, Canada
Rehnstam AS, Norqvist A, Wolf-Watz H, Hagström A (1989) Identification of Vibrio anguillarum in fish by using partial $16 \mathrm{~S}$ rRNA sequences and a specific 16S rRNA oligonucleotide probe. Appl environ Microbiol 55:1907-1910

Stewart JE (1993) Infectious diseases of marine crustaceans In: Couch JA, Fournie JW (eds) Pathobiology of marne and estuarıne organısms. CRC Press, Inc, Boca Raton, FL, p $319-342$

Takahashı Y, Shımoyama Y, Momoyama K (1985) Pathogenicity and characteristics of Vibro sp. isolated from cultured kuruma prawns Penaeus japonicus Bate. Bull Japan Soc Sci Fish 51:721-730

Toyama T, Kita-Tsukamoto K. Wakabayashi H (1994) Identification of Cytophaga psychrophila by PCR targeted $16 \mathrm{~S}$ ribosomal RNA. Fish Pathol 29:271-275

Woese CR (1987) Bacterial evolution. Microbiol Rev 51: $221-271$

Manuscript first received: June 26, 1995

Revised version accepted: September 18, 1995 